\title{
Partial Purification and Characterization of a Thermostable Alkaline Protease from Lactobacillus brevis
}

\author{
Titilayo Olufunke Femi-Ola* and Desmond Olayinka Oladokun \\ Department of Microbiology, University of Ado-Ekiti, P. M. B. 5363, Ado-Ekiti, Nigeria. \\ E-mail: titifemi2006@yahoo.com
}

Received 30 November 2010; received in revised form 5 April 2011; accepted 13 August 2011

\begin{abstract}
Aims: The research was done to study the partial purification and characterization of thermostable alkaline protease from Lactobacillus brevis.

Methodology and Results: The enzyme was purified in a two-step procedure involving ammonium sulphate precipitation and Sephadex G-150 gel permeation chromatography. The protease was purified 8.04 fold with a yield of approximately $30 \%$ after purification with Sephadex G-150 column. It has a relative molecular weight of $33.2 \mathrm{kDa}$ and optimally active at a temperature of $60{ }^{\circ} \mathrm{C}$ and $\mathrm{pH} 9.0$. The maximum velocity $\mathrm{V}_{\max }$ and Michaelis constant $\mathrm{K}_{\mathrm{m}}$ of the protease produced during the hydrolysis of casein were $66.66 \mathrm{U} / \mathrm{mg}$ protein and $3.33 \mathrm{mg} / \mathrm{ml}$. It was strongly activated by $\mathrm{Ca}^{2+}$ and ethylene diamine tetra acetic acid (EDTA), mildly inhibited by $\mathrm{Na}^{+}, \mathrm{K}^{+}, \mathrm{Mg}^{2+}$ and Fe ${ }^{2+}$ and strongly inhibited by $\mathrm{Cu}^{2+}$ and $\mathrm{Hg}^{2+}$. The ability of the enzyme to improve the cleansing power of various detergents was also studied. Conclusion, significance and impact of study: The findings in this study suggest that the protease is a suitable candidate for detergent formulation and biotechnological applications.
\end{abstract}

Keywords: protease, Lactobacillus, alkaline, inhibitors and detergent

\section{INTRODUCTION}

Proteases are one of the most important classes of enzymes and are expressed throughout the animal kingdom, plant and as well as microbes (Dubey et al., 2007). Among the various proteases, bacterial proteases are the most significant compared with those of animals and plants (Gupta et al., 2002). This enzyme accounts for nearly $60 \%$ of the total worldwide enzyme sales (Adinarayana et al., 2003; Beg et al., 2003). There are acidic, alkaline and neutral proteases, but of all these, alkaline proteases are employed primarily as cleansing additives (Ward, 1995; Nehra et al., 2004). Alkaline protease of microbial origin possess considerable industrial potential due to their biochemical diversity and wide applications in tannery and food industries, medicinal formulations, detergents and processes like waste treatment, silver recovery and resolution of amino acid mixtures (Rao et al.,1998; Agarwal et al., 2004; Devi et al., 2008). One of the major drawbacks affecting the stability at alkaline $\mathrm{pH}$ of enzymes recovered from thermophiles is that enzymes from alkalophile confer stability in a wide $\mathrm{pH}$ range but are usually thermolabile (Griffin et al., 1992).

In this present study, the protease produced by Lactobacillus brevis was characterized. The results obtained showed that the protease may be applied as an effective detergent additive which is recommended for laundry/detergent producing industries.

\section{MATERIALS AND METHODS}

\section{Organisms and culture conditions}

The test isolate, Lactobacillus brevis used for this research was isolated from the hindgut of kola nut weevil Balanogastris kolae Desbr. It was cultured on nutrient agar to obtain the pure culture of this organism. The organism was grown in a basal medium containing $(\mathrm{g} / \mathrm{L})$ : $\mathrm{K}_{2} \mathrm{HPO}_{4}, 1.5 ; \mathrm{KH}_{2} \mathrm{PO}_{4}, 0.5 ; \mathrm{MgSO}_{4}, 0.05 ; \mathrm{NaCl}, 1.5$; $\left(\mathrm{NH}_{4}\right)_{2} \mathrm{SO}_{4}, 1.0 ; \mathrm{CaCl}_{2} \cdot 2 \mathrm{H}_{2} \mathrm{O}, 0.02 ; \mathrm{FeSO}_{4} \cdot 7 \mathrm{H}_{2} \mathrm{O} 0.02$; yeast extract, 0.5 ; sucrose, 0.5 and casein, 0.1 . The inocula for the experiments were prepared by growing the organism in nutrient broth (NB, Oxoid) at $35^{\circ} \mathrm{C}$ for $18 \mathrm{~h}$ on a rotary shaker (Gallenkamp). Sterilized medium $(500 \mathrm{~mL})$ in $1000 \mathrm{~mL}$ conical flasks was inoculated with $10 \mathrm{~mL}$ of inocula $\left(1.2 \times 10^{5}\right.$ cells $\left./ \mathrm{mL}\right)$. The flask was incubated at 35 ${ }^{\circ} \mathrm{C}$ on a rotary shaker $(120 \mathrm{rpm})$ for $48 \mathrm{~h}$ and then centrifuged at $5000 \mathrm{rpm}$ for $20 \mathrm{~min}$ at $4{ }^{\circ} \mathrm{C}$ to remove bacterial cells. The supernatant obtained was used as the crude extract for further studies.

\section{Protease assay}

The protease activity was determined a reaction mixture consisting of $1 \mathrm{~mL}$ of substrate solution (1\% casein in Tris$\mathrm{HCl}$ buffer, $\mathrm{pH} 8.0$ ) and $1 \mathrm{~mL}$ of the enzyme solution. The reaction mixture was incubated for $60 \mathrm{~min}$ at $40{ }^{\circ} \mathrm{C}$. The proteins were precipitated by adding $3 \mathrm{~mL}$ of $0.5 \%$ TCA and free amino acids released by protease from casein

\section{${ }^{\star}$ Corresponding author}


hydrolysis were estimated by Lowry et al. (1951) method. The protease activity was defined as mol of tyrosine released per min per $\mathrm{mL}$ of the enzyme.

\section{Protein assay}

Protein was determined by the method of Lowry et al. (1951) with bovine serum albumin (BSA) as the standard. The concentration of protein during purification studies was measured at an absorbance of $280 \mathrm{~nm}$.

\section{Purification and characterization of protease}

\section{Ammonium sulphate precipitation}

Fifty milliliters $(50 \mathrm{~mL})$ of crude enzyme was precipitated (fractional) with $\left(\mathrm{NH}_{4}\right)_{2} \mathrm{SO}_{4}$ (Analytical grade, B.D.H) at $70 \%(\mathrm{w} / \mathrm{v})$ saturation for $24 \mathrm{~h}$ at $4{ }^{\circ} \mathrm{C}$. The precipitate was centrifuged at $10,000 \mathrm{rpm}$ for $10 \mathrm{~min}$. The precipitate was redissolved in Tris- $\mathrm{HCl}$ buffer $(\mathrm{pH}$ 7.8) and dialyzed against several volumes of the same buffer for $24 \mathrm{~h}$ at 4 ${ }^{\circ} \mathrm{C}$ using acetylated cellophane tubing prepared from Visking dialysis tube (Gallenkamp) as described by Whitaker et al. (1963).

\section{Sephadex G-150 Gel filtration chromatography}

Sephadex G-150 (Sigma, Aldrich) was packed into a column $(1.5 \times 75 \mathrm{~cm})$ and equilibrated with Tris- $\mathrm{HCl}$ buffer $(\mathrm{pH}$ 7.8).The column was eluted with the same buffer at a flow rate of $20 \mathrm{~mL} / \mathrm{h}$. A fraction of $2.0 \mathrm{~mL}$ were collected at interval of $30 \mathrm{~min}$ and the absorbance at $280 \mathrm{~nm}$ was read using spectrophotometer (Jenway, 6305). For determination of molecular weight by gel filtration the standards used were: gamma globulin, $15 \mathrm{kDa}$; alpha chymotrypsinogen, $25.7 \mathrm{kDa}$; ovalbumin, $45 \mathrm{kDa}$; bovine serum albumin, $66 \mathrm{kDa}$ and creatine phosphokinase, 81 kDa (Sigma, UK).

\section{Effect of pH on protease activity}

Substrates ( $1 \%$ casein) having $\mathrm{pH}$ ranging from 5.0 to 8.0 were prepared using $0.05 \mathrm{M}$ of different buffer system (Glycine-HCl, pH 3.0; acetate buffer, $\mathrm{pH} 4.0$ and 5.0; phosphate buffer $\mathrm{pH} 6.0$ and 7.0; Tris- $\mathrm{HCl}, \mathrm{pH} 8.0$ ). Enzyme activity was determined at $40^{\circ} \mathrm{C}$.

\section{Effect of temperature on protease activity and stability}

Protease activity was assayed by incubating the enzyme reaction mixture at different temperatures, ranged from 20 ${ }^{\circ} \mathrm{C}$ to $80^{\circ} \mathrm{C}$ for $1 \mathrm{~h}$. The thermal stability at temperature from $50^{\circ} \mathrm{C}$ to $80^{\circ} \mathrm{C}$ was also determined. Samples were taken at $5 \mathrm{~min}$ intervals and analyzed for protease activity.

\section{Effect of substrate concentration on protease activity}

The effect of substrate concentration [S] on the rate of enzyme action was studied using [S] values from 2.0 $\mathrm{mg} / \mathrm{mL}$ to $10.0 \mathrm{mg} / \mathrm{mL}$. The Lineweaver-Burke plot was made. Both the $V_{\max }$ and $K_{m}$ of the enzyme were calculated.

\section{Effect of heavy metals on enzyme activity}

A stock solution of $0.01 \mathrm{M}$ of $\mathrm{HgCl}_{2}$ and EDTA were prepared. Two milliliters of each salt solution was mixed with $2 \mathrm{~mL}$ of substrate solution. The substrate/chemical mixture was incubated at room temperature for $5 \mathrm{~min}$ before it was used in enzyme assay.

\section{Effect of cations}

A stock solution of $0.01 \mathrm{M}$ of each salt was prepared. The effects of some salts/cations $\left(\mathrm{NaCl}, \mathrm{KCl}, \mathrm{CaCl}_{2}, \mathrm{CuSO}_{4}\right.$, $\mathrm{MgSO} 4$, and $\mathrm{FeCl}_{2}$ ) on enzyme activity was also determined. The substrate/salts mixture was also incubated at room temperature for $5 \mathrm{~min}$ before it was used for enzyme assay.

\section{De-staining ability of the enzyme}

The application of protease as a detergent additive was studied on white cloth pieces $(4 \times 4 \mathrm{~cm})$ stained with blood. The de-staining property was studied by dipping pieces of cloth artificially stained with blood either in detergent solution supplemented with crude enzyme followed by incubation for $15 \mathrm{~min}$ at $60{ }^{\circ} \mathrm{C}$. The stained cloth pieces were taken in separate flasks. The following sets were prepared and studied:

Flask with distilled water $(100 \mathrm{~mL})+$ stained cloth

Flask with distilled $\mathrm{H}_{2} \mathrm{O}(100 \mathrm{~mL})+$ stained cloth $+1 \mathrm{~mL}$ Omo detergent $(7 \mathrm{mg} / \mathrm{mL})$

Flask with distilled $\mathrm{H}_{2} \mathrm{O}(100 \mathrm{~mL})+$ stained cloth $+1 \mathrm{~mL}$ Omo detergent $(7 \mathrm{mg} / \mathrm{mL})+2 \mathrm{~mL}$ enzyme solution.

After incubation cloth pieces were taken out, rinsed with water and drained. The untreated cloth pieces stained with blood were taken as control.

\section{RESULTS AND DISCUSSION}

\section{Purification of Lactobacillus brevis protease}

The partial purification of this enzyme using ammonium sulphate precipitation and gel filtration chromatography are shown on Table 1 and Figure 1 respectively. Multiple protein peaks produced by the isolate are shown on the elution profile and a single activity peak was observed. The two step purification process yielded a partially purified protease with a specific activity of $29.15 \mathrm{U} / \mathrm{mg}$ protein and a purification of approximately eight fold with $29.9 \%$ yield of proteins. The molecular weight of the protease produced was estimated to be $33.2 \mathrm{kDa}$.

\section{Characteristics of the purified enzyme (pH optimum)}

The highest protease activity was found to be at $\mathrm{pH} 9.0$ 
Mal. J. Microbiol. Vol 8(1) 2012, pp. 1-5

Table 1: Purification of extracellular protease of $L$. brevis

\begin{tabular}{|c|c|c|c|c|c|c|}
\hline Fraction & Vol. (mL) & $\begin{array}{l}\text { Protein content } \\
(\mathrm{mg} / \mathrm{mL})\end{array}$ & $\begin{array}{l}\text { Protease activity } \\
\text { (U) }\end{array}$ & $\begin{array}{l}\text { Specific activity } \\
\text { (U/mg of protein) }\end{array}$ & Yield (\%) & $\begin{array}{l}\text { Purification } \\
\text { fold }\end{array}$ \\
\hline $\begin{array}{l}\text { Crude enzyme } \\
\left(\mathrm{NH}_{4}\right)_{2} \mathrm{SO}_{4}\end{array}$ & 50 & 1835.5 & 6650 & 3.62 & 100 & 1.00 \\
\hline $\begin{array}{l}\text { Precipitation } \\
\text { Gel filtration }\end{array}$ & $\begin{array}{l}20 \\
45\end{array}$ & $\begin{array}{l}591.2 \\
550.3\end{array}$ & $\begin{array}{l}5926 \\
516047\end{array}$ & $\begin{array}{l}10.02 \\
29.15\end{array}$ & $\begin{array}{l}32.4 \\
29.9\end{array}$ & $\begin{array}{l}2.76 \\
8.04\end{array}$ \\
\hline
\end{tabular}

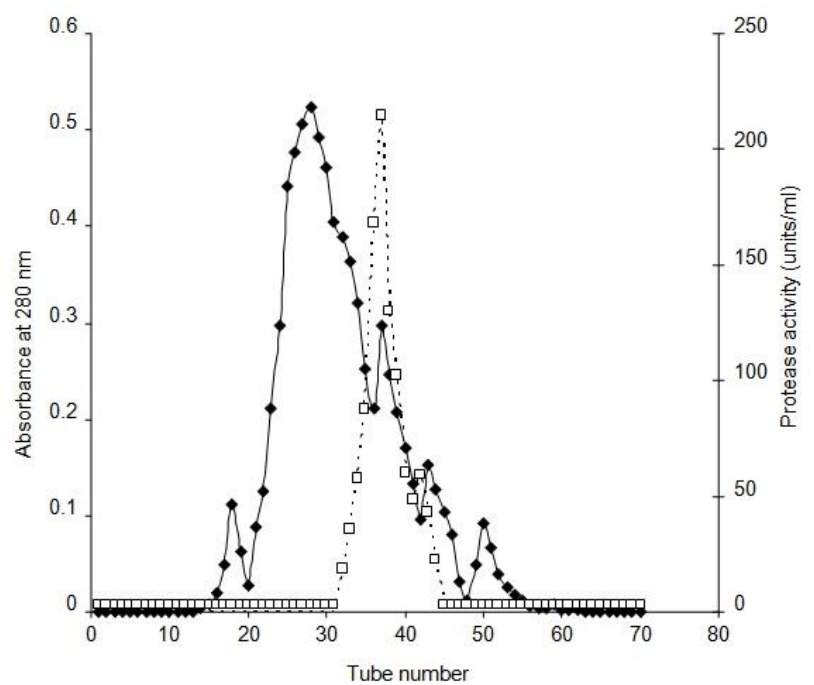

Abs $280 \mathrm{~nm}(\diamond)$, Protease activity $(\mu \mathrm{mol} / \mathrm{min} / \mathrm{mL})(\square)$

Figure 1: Elution profile of protease produced by Lactobacillus brevis on Sephadex G - 150 (1.5 x 75) column equilibrated with $0.1 \mathrm{M}$ Tris $-\mathrm{HCl}$ buffer, $\mathrm{pH} 7.8$. Flow rate at $20 \mathrm{~mL} / \mathrm{h}$.

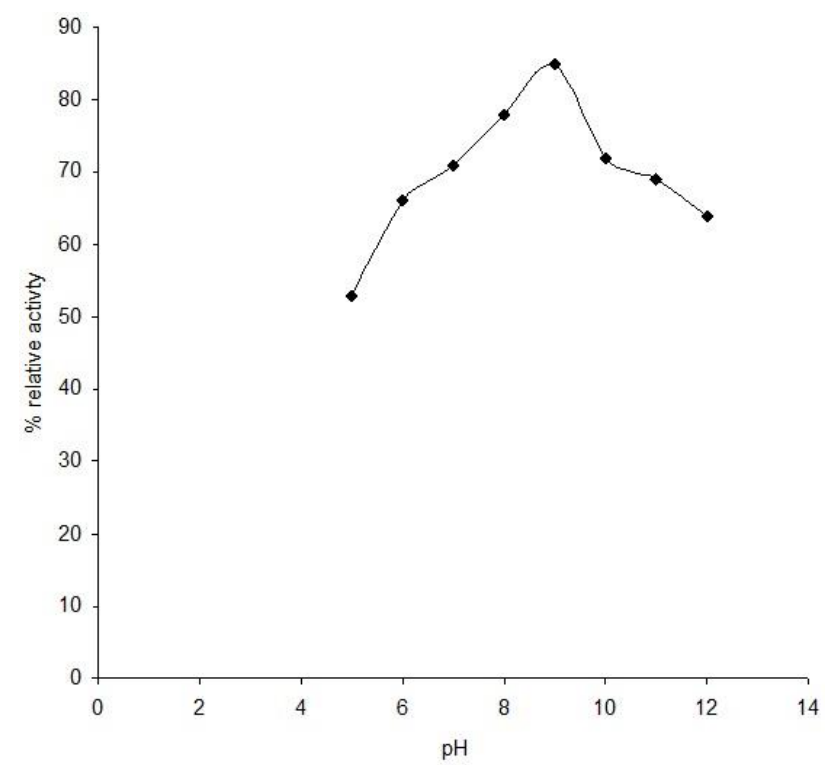

Figure 2: Effect of $\mathrm{pH}$ on the activity of L. brevis protease.
(Figure 2). This is similar to the result of the protease activity of Bacillus subtilis PE-11 whose maximum activity was found to be at pH 10.0 (Adinarayana et al., 2003).

\section{Temperature optimum and stability}

The optimum temperature for the protease activity was 60 ${ }^{\circ} \mathrm{C}$. The activity gradually declined at temperature beyond $60{ }^{\circ} \mathrm{C}$ (Figure 3). Adinarayana et al., (2003) reported a similar result of temperature optimum of $60{ }^{\circ} \mathrm{C}$ for protease derived from Bacillus sp BZI-2. Thermo stability profile shows that the enzyme activity was stable at $50{ }^{\circ} \mathrm{C}$ and $60{ }^{\circ} \mathrm{C}$ as it retained almost all its initial activity. Its activity was reduced at $70{ }^{\circ} \mathrm{C}$ and $80^{\circ} \mathrm{C}$ respectively (Figure 4).

Lactobacillus brevis protease was however confirmed as stable thermally as it retained $60 \%$ activity at $80{ }^{\circ} \mathrm{C}$ for $60 \mathrm{~min}$.

\section{Kinetics}

The $V_{\max }$ and $K_{m}$ values for thermo stable alkaline protease from Lactobacillus brevis were determined from

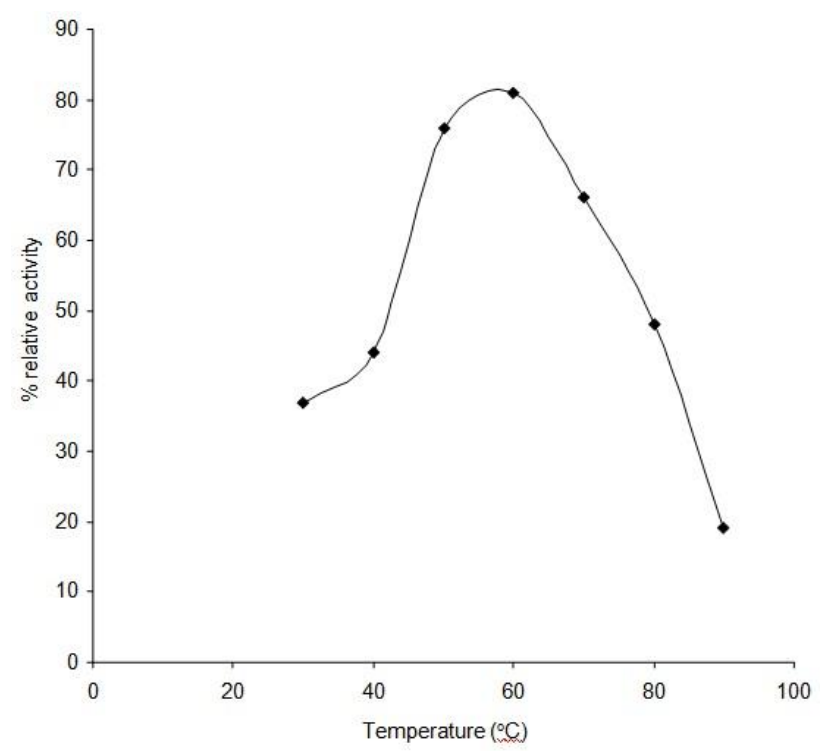

Figure 3: Effect of temperature on the activity of $L$. brevis protease. 


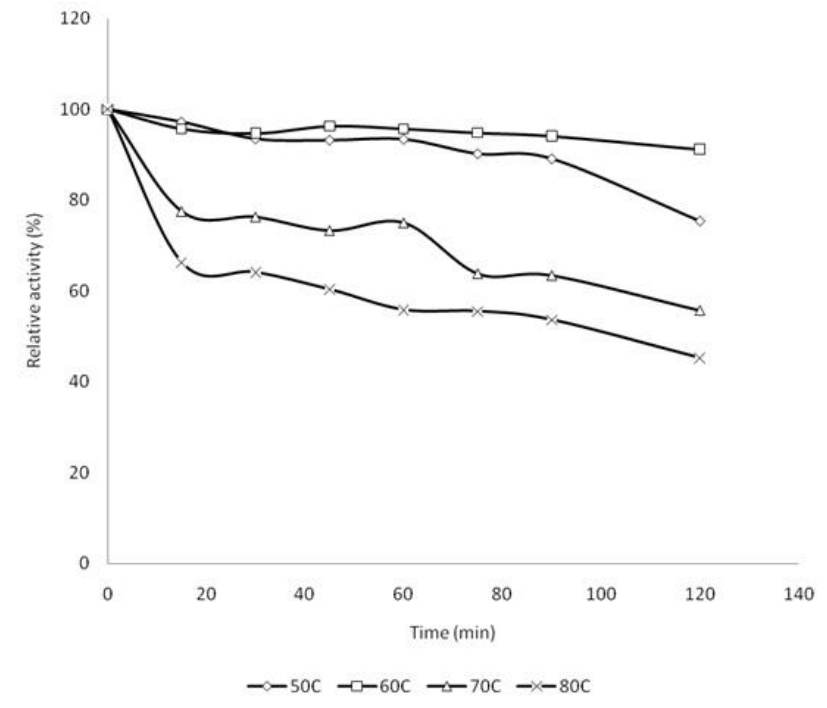

Figure 4: Thermal stability of L. brevis protease.

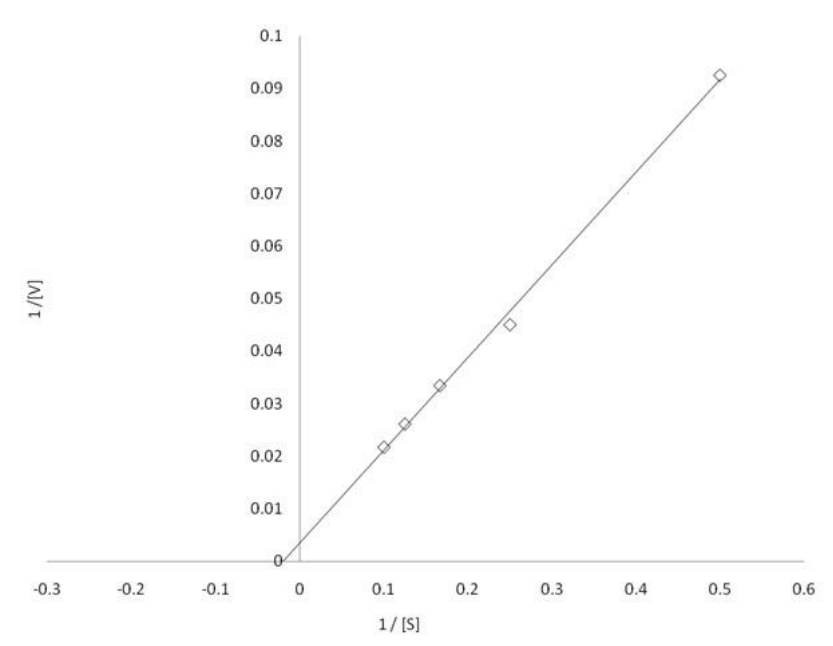

Figure 5: Lineweaver- Burke plot of protease produced by L. brevis.

Lineweaver- Burke plots. This revealed that the protease had a $V_{\max }$ of $250 \mathrm{U} / \mathrm{mg}$ protein and $\mathrm{K}_{\mathrm{m}}$ value $50 \mathrm{mg} / \mathrm{mL}$ (Figure 5). Several authors have reported values far lower than these (Kaur et al., 1998; Devi et al., 2008).

\section{Effect of various salts}

The salts that were used are categorized into activators $\left(\mathrm{CaCl}_{2}\right.$ and EDTA), mild inhibitor $\left(\mathrm{NaCl}, \mathrm{KCl}, \mathrm{MgSO}_{4}\right.$ and $\mathrm{FeCl}_{2}$ ) and strong inhibitor $\left(\mathrm{CuSO}_{4}\right.$ and $\mathrm{HgCl}_{2}$ ) (Table 2). Devi et al. (2008) reported that $\mathrm{CaCl}_{2}$ enhanced the activity of protease enzyme produced by Aspergillus niger. Tsuchiya et al. (1987) reported that the proteases isolated from Cephalosporium sp. was inhibited by $\mathrm{Hg}^{2+}, \mathrm{Mn}^{2+}$, $\mathrm{Cu}^{2+}, \mathrm{Ca}^{2+}$ and these same ions were found to inhibit the activity of the alkaline proteases secreted by Bacillus polymyxa (Kaur et al., 1998). Nehra et al. (2004) reported that $\mathrm{Mg}^{2+}$ activated the alkaline protease produced by Aspergillus sp. These reports are in agreement with our results.

\section{De-staining properties with detergents}

As shown in Figure 6, after 10 min of incubation at $60{ }^{\circ} \mathrm{C}$ the detergent solution supplemented with the enzyme was able to remove the blood strains completely, while the detergent solution only could not remove it. Bhosale et al. (1995) has reported high activity of alkaline proteases of Conidiobolus coronatus showing compatibility at $50{ }^{\circ} \mathrm{C}$ in the presence of $25 \mathrm{mM} \mathrm{CaCl}_{2}$ with varieties of detergents. Adinarayana et al. (2003) worked with Bacillus subtilis PE II proteases and reported its compatibility and stability with various locally available detergents at $60^{\circ} \mathrm{C}$ in the presence of $\mathrm{CaCl}_{2}$ and glycine as stabilizers.

Table 2: Effect of salts on the activity of L. brevis protease

\begin{tabular}{ll}
\hline Salt & Relative activity (\%) \\
\hline Control & 100 \\
$\mathrm{NaCl}$ & 83 \\
$\mathrm{KCl}$ & 92 \\
$\mathrm{CaCl}_{2}$ & 101 \\
$\mathrm{MgSO}_{4}$ & 79 \\
$\mathrm{CuSO}_{4}$ & 49 \\
$\mathrm{FeCl}_{2}$ & 76 \\
$\mathrm{HgCl}$ & 34 \\
EDTA & 106 \\
\hline
\end{tabular}

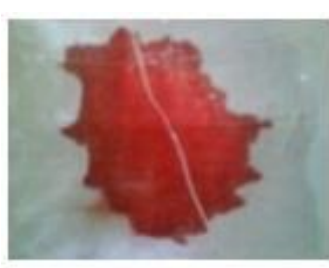

a

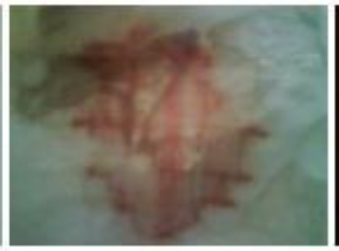

b

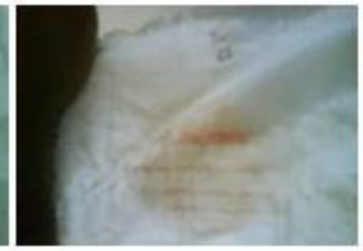

C

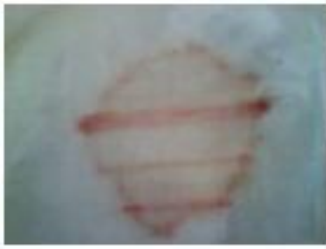

d

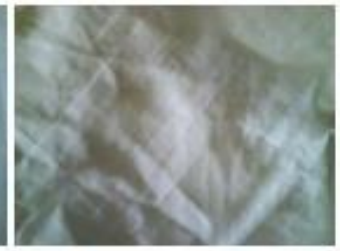

e

Figure 6: Blood de-staining activity of crude alkaline protease of Lactobacillus brevis \{a, 0 min; b, 5 min (detergent only); c, 5 min (detergent + enzyme); d, 10 min (detergent only); e, 10 min (detergent + enzyme)\}. 


\section{REFERENCES}

Adinarayana, K., Ellaiah, P. and Prasad, D. S. (2003). Purification and partial characterization of thermostable serine alkaline protease from a newly isolated Bacillus subtilis PE-11. AAPS Pharmaceutical Science Technician 4, 56-63.

Agarwal, D., Patidar, P., Banergee, T. and Patil, S. (2004). Production of alkaline protease by Penicillium sp. Under SSF conditions and its application to soy protein hydrolysis. Process Biochemistry 39, 977-981.

Beg, Q. K., Sahai, V. and Gupta, R. (2003). Statistical media optimization and alkaline protease production from Bacillus mojavensis in a bioreactor. Process Biochemistry 39, 203-209.

Bhosale, S. H., Roa, M. B., Desh, V. V. And Srinivasan, M. C. (1995). Thermo stability of high activity alkaline protease from Conidiobolus coronatus (NCL 86.8.20). Enzyme Microbial Technology 17, 136-139.

Devi, K. M., Banu, A. R., Gnanaprabhal, G. R., Pradeep, B. V. and Palaniswany, M. (2008). Purification, characterization of alkaline protease enzyme from native isolate of Aspergillus niger and its compatibility with commercial detergents. Indian Journal of Science and Technology 1, 7-13.

Dubey, K. V., Monu, P., Bishal, K. S. and Medichan, V. J. (2007). Papain-like proteases: Applications of their inhibitor. African Journal of Biotechnology 6(9), 10771086.

Griffin, H. L., Greene, R. V. and Cotta, M. A. (1992). Isolation and characterization of a protease from the marine shipworm bacterium. Current Microbiology 24, 111-117.

Gupta, R., Beg, Q. K. and Lorenz, P. (2002). Bacterial alkaline protease: Molecular approaches and industrial applications. Applied Microbiology and Biotechnology 59(1), 15-32.

Kaur, M., Dhillon, S., Chaudhary, K. And Singh, K. (1998). Purification, characterization of thermo stable alkaline protease from Bacillus polymyxa. Indian Journal of Microbiology 38, 63-67.

Lowry, Q. H., Rosebrough, N. J., Farr, A. L. and Randall, R. L. (1951). Protein measurement with the folin phenol reagent. Journal of Biological Chemistry 193, 265-273.

Nehra, K. S., Singh, A., Sharma, J., Kumar, R. and Dhillon, I. (2004). Production and characterization of alkaline protease from Aspergillus species and its compatibility with commercial detergents. Asian Journal of Microbiology Biotechnology and Environmental Science 6, 67-72.

Rao, M. B., Tanksale, A. M., Ghalge, M. S. and Desphande, V. V. (1998). Molecular and biotechnological aspects of microbial proteases. Microbiology, Molecular Biology Review 62, 597-635.

Tsuchiya, K., Arai, T., Seki, K. and Kimura, T. (1987). Purification and some properties of alkaline protease from Cephalosporium sp KM338. Agricultural Biology and Chemistry 51, 2959-2965.
Ward, O. P. (1995). Proteolytic enzymes. In: Comprehensive Biotechnology. Vol. 3. Blanch, $\mathrm{H}$. W., Drew, S., Wang, D. I. (eds.). Oxford Pergamon Press, U. K. pp. 789-818.

Whitaker, D. R., Hanson, K. R. and Datta, P. K. (1963). Improved procedure for preparation and characterization of Myrothecium cellulase. Part 2: Purification Procedure. Canadian Journal of Biochemistry and Physiology 41, 671-696. 